\title{
Monitoring Lead Pollution Near a Storage Battery Recycling Plant in Taiwan, Republic of China
}

\author{
C.-Y. Yeh', H.-Y. Chiou', R.-Y. Chen', K.-H. Yeh', W.-L. Jeng², B.-C. Han ${ }^{1}$ \\ School of Public Health, Taipei Medical College, Taipei, Taiwan, Republic of China \\ ${ }^{2}$ Institute of Oceanography, National Taiwan University, Taipei, Taiwan, Republic of China
}

Received: 27 May 1995/Revised: 15 September 1995

\begin{abstract}
This study presents the distribution of blood lead levels and lead in various environmental samples (water, sediments, soils, and air) near the Shing-Yie storage battery recycling plant in Taiwan before (July 1990 to June 1991) and after (July 1992 to June 1993) amelioration. Before amelioration, the average blood lead levels in the neighborhood of the plant were in the range of $10.55 \pm 5.7$ to $12.28 \pm 7.9 \mu \mathrm{g} / \mathrm{dl}$. After amelioration, relatively lower average concentrations of blood lead (range $8.35 \pm 3.0$ to $9.13 \pm 2.5 \mu \mathrm{g} / \mathrm{dl}$ ) were generally found; however, these averages were still higher than that $(7.79 \pm 3.5 \mu \mathrm{g} / \mathrm{dl})$ from other lead-unpolluted areas of Taiwan. An exceedingly high geometric mean (GM) lead concentration $(128 \mu \mathrm{g} / \mathrm{L})$ was found in the downstream river water of the Tawulum River passing by the plant. The concentrations of lead ( $\mathrm{GM}=372$ and $418 \mu \mathrm{g} / \mathrm{g})$ in the downstream river sediments were higher than those (GM $=123$ and $158 \mu \mathrm{g} / \mathrm{g})$ in the upstream river sediments before and after amelioration, respectively. Furthermore, lead species in river sediments were analyzed by a sequential leaching technique. The sum of phases I, II, and III accounted for $83.7 \%$ of total lead at station $\mathrm{R}_{2}$ (nearest to the plant). Maximum lead concentration $\left(\mathrm{GM}=2402 \mu \mathrm{g} / \mathrm{g}\right.$ ) in dust at the soil surface from station $S_{1}$ (nearest to the plant) was much higher than those from the other stations by about 18 times before amelioration. However, the maximum value dropped to $1,155 \mu \mathrm{g} / \mathrm{g}$ after amelioration. On the whole, the geometric mean concentration of lead in dust at the soil surface nearest to the plant was $>1,000 \mu \mathrm{g} / \mathrm{g}$ and decreased to $<100 \mu \mathrm{g} / \mathrm{g}$ in the $15-30 \mathrm{~cm}$ depth soil about 2 $\mathrm{km}$ away from the plant. Before amelioration, the geometric mean lead concentration of $4.57 \mu \mathrm{g} / \mathrm{m}^{3}$ (range $0.102-37.6$ $\mu \mathrm{g} / \mathrm{m}^{3}$ ) in the air near the plant was higher than that at the background locations, the geometric mean value of which was $0.08 \mu \mathrm{g} / \mathrm{m}^{3}$.
\end{abstract}

Correspondence to: B.-C. Han
Taiwan is a modern industrialized island country with a population of about 21 million and a strong economy. However, due to dense population and rapid industrial expansion, the different environments of Taiwan are suffering an ever-increasing impact from various human activities (Han et al 1992b; Han et al. 1994b; Jeng and Han 1994). Heavy metal pollution is the most serious and one of the most studied environmental problems in Taiwan. Lead exposure remains a significant public health concern (Jang 1989; Rabinowitz et al. 1992) due to the fact that the metal is widespread in our environment and has been shown to be toxic even at low doses, especially for the fetus or for children (Needleman et al. 1990; Greene et al. 1992).

Exposure of lead for the general public comes mainly from the airborne dust containing lead particulates and food or water contaminated by lead. However, as a special case, a five-monthold female infant died as a result of long-term feeding with an ancient Chinese medicine, "Ba-pao-neu-hwang-san". The drug contained lead at $44,000 \mu \mathrm{g} / \mathrm{g}$. This medicine is still widely used by ordinary people (Chi et al. 1993).

In Taiwan with the increasing awareness of lead as an environmental hazard, there is growing inquiry regarding tissue levels and recognition of groups at high risk. In 1987, a case of lead poisoning occurred in workers at a lead battery recycling factory in northern Taiwan. Jang (1989), Rabinowitz et al. (1991, 1992), and Wang et al. (1992) conducted a follow-up study of the impact of the factory's lead contamination on the incidence of occupational and environmental diseases. Their studies found that the blood lead level exceeded $40 \mu \mathrm{g} / \mathrm{dl}$ in $85 \%$ of the factory workers. The blood lead level of children from a neighboring kindergarten was found to be higher than that of the control group, and a decrease in their IQ was also seen (Jang 1989). An examination of students from a nearby elementary school revealed that lead content in their teeth was higher than that of the teeth of their Taipei City counterparts (Rabinowitz et al. 1991). In addition, Wang et al. (1992) also reported that (1) air lead levels were $12.9 \pm 11.4$ and $12.8 \pm 8.00 \mu \mathrm{g} / \mathrm{m}^{3}$ at $50 \mathrm{~m}$ and $100 \mathrm{~m}$, respectively, from the Shing-Yie smelter compared to $1.2-1.9 \mu \mathrm{g} / \mathrm{m}^{3} 1 \mathrm{~km}$ away, (2) lead concentrations in the surface soil near the smelter were 


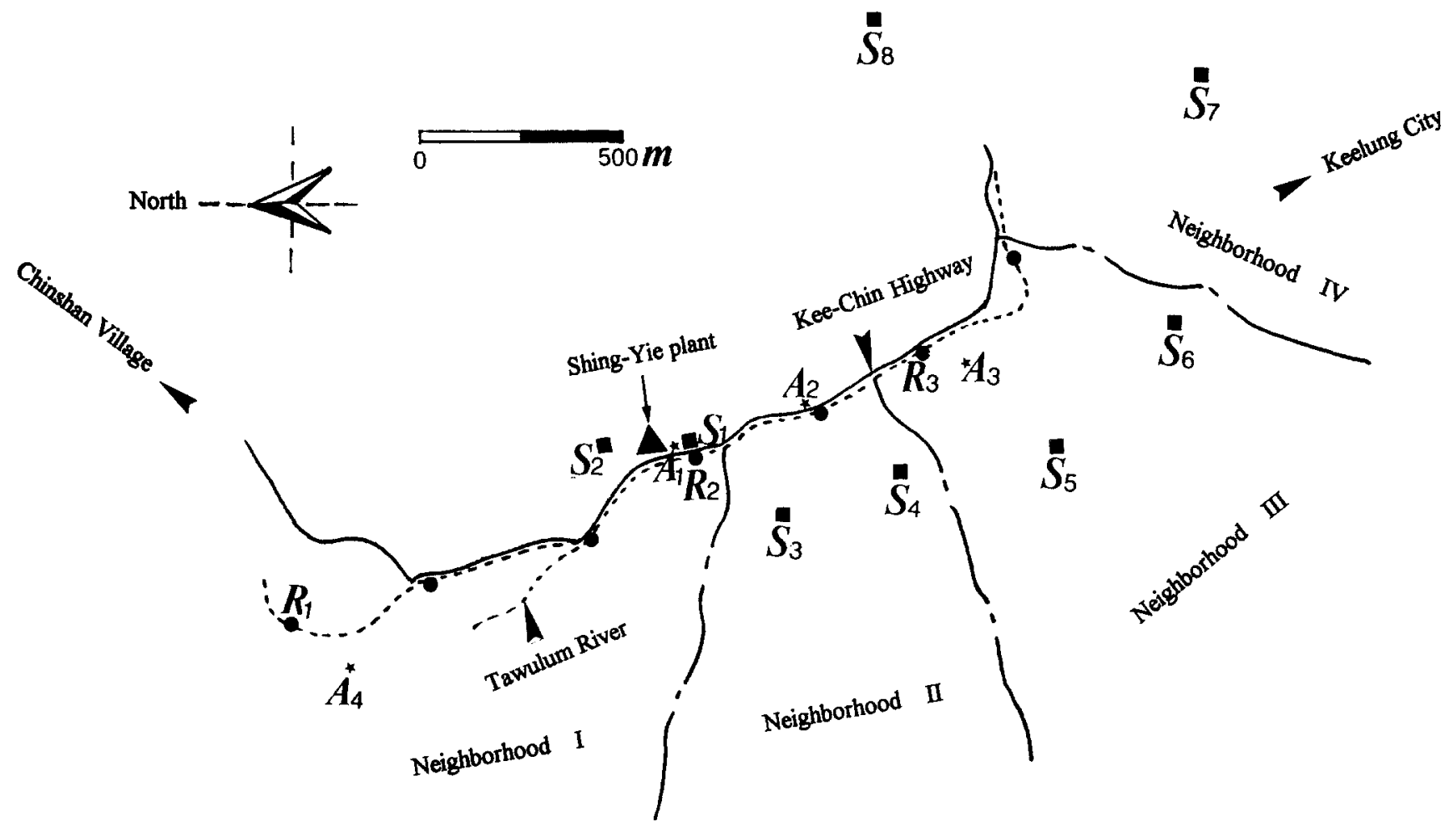

Fig. 1. Sampling locations of human blood, river water $(\bullet)$, sediments $(\bullet)$, soils $(\bullet)$, and air $(\star)$ around the Shing-Yie storage battery recycling plant (4)

up to $4,100 \pm 3,500 \mu \mathrm{g} / \mathrm{g}$ and decreased to $21.8 \pm 12.5 \mu \mathrm{g} / \mathrm{g}$ in the $15-30 \mathrm{~cm}$ depth soil, and (3) 22 out of 36 exposed children had a blood lead level exceeding $15 \mu \mathrm{g} / \mathrm{dl}$. However, there is much circumstantial evidence that lead in environmental samples had an important influence on human uptake (Thornton et al. 1990; Mielke 1991, 1992; Francek et al. 1994), but there was a pressing need for further research. Furthermore, there is little information on the relationships between lead in environmental samples and exposure assessment of humans. Therefore, this study presents the distribution of blood lead levels and lead in various environmental samples (such as water, sediments, soils, and air) near the Shing-Yie storage battery recycling plant before (July 1990 to June 1991) and after (July 1992 to June 1993) amelioration (some measures taken to reduce pollution, e.g., installing dust collectors). The paper also preliminarily evaluated the relationship between lead concentrations in the environment and blood lead levels in humans. Furthermore, the purpose of this work was to better understand the lead contamination impact on the environment and human health near a storage battery recycling plant.

\section{Materials and Methods}

Environmental samples including tap water, river water, sediments, soils, and air were sampled around the Shing-Yie storage battery recycling plant of Keelung in northern Taiwan during two periods-before (July 1990 to June 1991) and after (July 1992 to June 1993) amelioration. Although water wells were few in the area, analyzing well water was also included since some people might be exposed to the well water. Sampling for river water, sediment, soil, and air was done every season. Sampling locations are shown in Figure 1. It is noted that all sampling stations are mostly located in the south of Kee-Chin highway. This was based on the residential quarter being in the south of KeeChin highway, and non-residential areas (bumpy hills) in the north.

Water samples were returned to the laboratory in an icebox and refrigerated at $4^{\circ} \mathrm{C}$ until processed. All samples were analyzed for total lead concentrations after acidification to $\mathrm{pH} 2$ with conc. $\mathrm{HNO}_{3}$ by measuring $\mathrm{pH}$ with a $\mathrm{pH}$ meter, and determined by differential pulse anodic stripping voltammetry (DPASV; EG\&G model 384B Polarographic Analyzer).

Sediments in the river bed were collected along with the river water, dried ovemight, and sieved ( $<63 \mu \mathrm{m}$ mesh) to obtain the mud fraction. Soil surface dust was collected by brushing, and surface soil samples were taken from $0-15$ and $15-30 \mathrm{~cm}$ depths at various locations. Accurately, $0.20 \mathrm{~g}$ of the dried and homogenized samples were placed in a $50 \mathrm{ml}$ capped polypropylene centrifuge tube with different reagents to release different phases of lead as shown in Figure 2 (Han et al. 1992a). Total lead concentrations were determined by flame AAS (Hitachi Z-8000) at $283.3 \mathrm{~nm}$.

Total particulates in air were collected with a Kimoto and Anderson high volume sampler from 4 different sites, i.e., 50, 100, 950, and $1200 \mathrm{~m}$ away from the Shing-Yie plant. The loaded glass fiber filters were digested and analyzed for the lead concentrations using graphite AAS (Han et al. 1994a).

A total of 931 men and 843 women aged 8 to 65 years residing within $2 \mathrm{~km}$ around the Shing-Yie plant participated in the study on a volunteer basis after issuing public notice. Ten percent of the population was sampled as representative. Each family was asked to fill out a questionnaire regarding their birth date, education, and occupational status (especially any occupational exposure to lead), whether they lived beside a main street with major traffic, and other background information.

Whole blood samples were taken by venipuncture in a vacuumcollection tube with top color green containing sodium heparin as anticoagulant. The samples were stored in a refrigerator and analyzed 


\author{
Samples \\ 1M Ammonium Acetate, $15 \mathrm{ml}, \mathrm{pH}=7,30 \mathrm{mins}$ \\ Exchangeable phase \\ $1 \mathrm{M}$ Sodium Acetate, $20 \mathrm{ml}, \mathrm{pH}=5,5 \mathrm{hrs}$ \\ Carbonates phase \\ 1M Sodium Acetate $+0.25 \mathrm{M}$ Hydroxylamine Hydrochloride, $20 \mathrm{ml}$, \\ $\mathrm{pH}=5$, overnight \\ Easily reducible Fe \& Mn oxides phase \\ $25 \%$ Acetic Acid +0.25M Hydroxylamine Hydrochloride, $25 \mathrm{ml}, 6 \mathrm{hrs}$ \\ Resistant crystalline Mn oxides phase \\ (a). Add $3 \mathrm{ml}$ of $0.01 \mathrm{~N} \mathrm{HNO}_{3}+5 \mathrm{ml}$ of $30 \% \mathrm{H}_{2} \mathrm{O}_{2}$ heat to $85^{\circ} \mathrm{C}$ \\ for $2 \mathrm{hrs}$. \\ (b). Add $2 \mathrm{ml}$ of $0.01 \mathrm{~N} \mathrm{HNO}_{3}+3 \mathrm{ml}$ of $30 \% \mathrm{H}_{2} \mathrm{O}_{2}$ heat to $85^{\circ} \mathrm{C}$ \\ for $3 \mathrm{hrs}$. \\ (c). Cool and add $10 \mathrm{ml}$ of $1 \mathrm{M}$ Ammonium Acetate $(\mathrm{pH}=2)$, shake \\ overnight \\ Residual organic matter and sulphides phase \\ Residual digest $\mathrm{HF} / \mathrm{HNO}_{3}(1: 1)$ \\ Lattic held material phase
}

Fig. 2. Flow chart showing the sediment and soil sequential extraction scheme (after Han et al. 1992a) as soon as possible (within $24 \mathrm{~h}$ ) (Berode et al. 1991). The blood of inhabitants were $5 \mathrm{ml}$ samples for measurements of lead, zinc proporphyrin (ZPP), hemoglobin ( $\mathrm{Hb})$, and serum ferritin. Determination of blood lead levels was performed by graphite AAS (Han et al. 1991).

For statistical analyses, left skewed data were normalized by logarithmic transformation. Accordingly, geometric mean (GM) values were reported. A one-way analysis of variance (ANOVA), students ttests, and paired t-test were used to study differences of blood lead levels between four neighborhoods and sampling periods of each neighborhood.

\section{Results and Discussion}

\section{Quality Assurance of Lead in Blood and Environmental Samples}

Replicate analysis of standard reference materials (SRM) (river water SLRS-2; river sediment CRM 320; light sandy soil BCR 142; metals on filter media 2676C; ContoxBlood lead controls) from the National Research Council Canada, the Commission of the European Communities, the U.S. National Bureau of Standards, and the KLI Company showed good accuracy $(<20 \%)$ with all results comparable with certified values. For example, $0.130 \pm 0.020 \mu \mathrm{g} / \mathrm{L}$ was found as compared to the $\mathrm{SRM}$ for river water reference value of $0.129 \pm 0.011 \mu \mathrm{g} / \mathrm{L}$. On the other hand, replicate analysis of various SRM in the experiments also showed good precision (coefficients of variation were $19 \%$ for blood, $15 \%$ for river water, $2.7 \%$ for river sediment, $1.6 \%$ for light sandy soil, and $7.9 \%$ for air filter paper). The certified and experimental values for each SRM are listed in Table 1.

\section{Blood Lead Concentrations}

Mean, standard deviation, and students t-test of the observed blood lead level distributions in four neighborhoods are presented in Table 2. Analysis of variance (ANOVA) revealed that the average blood lead levels differed significantly between sampling neighborhoods and between sampling periods (Table 2). In addition, the results indicate that the average blood lead levels collected from 4 different neighborhoods in July 1992June 1993 were lower than those in July 1990-June 1991. The reason is that the Shing-Yie plant stopped operation by the EPA of ROC from July 1991 and that some amelioration action was taken. The cause of the high blood lead levels was identified as lead pollution due to discharges from the Shing-Yie lead recycling operation (Han et al. 1991; Wang et al. 1992). However, relatively high average concentrations of blood lead (range from $8.35 \pm 3.0$ to $9.13 \pm 2.5 \mu \mathrm{g} / \mathrm{dl}$ ) were generally found in samples from people residing around the Shing-Yie plant in July 1992-June 1993 compared with those $(7.79 \pm 3.5 \mu \mathrm{g} / \mathrm{dl})$ from other lead-unpolluted areas of Taiwan. From students 
Table 1. Determination of lead in standard reference material (SRM) by FAAS, GAAS, and DPASV

\begin{tabular}{lllccc}
\hline SRM & Method & $\begin{array}{l}\text { Value obtained } \\
\text { in our lab. }\end{array}$ & $\begin{array}{l}\text { Certified } \\
\text { value }\end{array}$ & $\begin{array}{l}\text { Coefficients of } \\
\text { variation }(\%)\end{array}$ & $\begin{array}{l}\text { Accuracy } \\
(\%)\end{array}$ \\
\hline Blood & GAAS & $24.0 \pm 4.5 \mu \mathrm{g} / \mathrm{dl}$ & $20.0 \pm 7.0 \mu \mathrm{g} / \mathrm{dl}$ & 19 & +20 \\
River water & DPASV & $0.130 \pm 0.020 \mu \mathrm{g} / \mathrm{L}$ & $0.129 \pm 0.011 \mu \mathrm{g} / \mathrm{L}$ & 15 & +0.77 \\
River sediment & FAAS & $40.8 \pm 1.1 \mu \mathrm{g} / \mathrm{g}$ & $42.3 \pm 1.6 \mu \mathrm{g} / \mathrm{g}$ & 2.7 & 1.6 \\
Light sandy soil & FAAS & $38.0 \pm 0.6 \mu \mathrm{g} / \mathrm{g}$ & $37.8 \pm 0.9 \mu \mathrm{g} / \mathrm{g}$ & 7.9 & +0.53 \\
Air filter paper & GAAS & $8.31 \pm 0.7 \mu \mathrm{g} / \mathrm{paper}$ & $7.47 \pm 0.011 \mu \mathrm{g} /$ paper & +10 \\
\hline
\end{tabular}

FAAS: Flame atomic absorption spectrophotometry

GAAS: Graphite atomic absorption spectrophotometry

DPASV: Differential pulse anodic stripping voltammetry

Table 2. Distribution of average blood lead levels $(\mu \mathrm{g} / \mathrm{dl})$ in four neighborhoods during two sampling periods. Data are presented as mean \pm 1 s.d.

\begin{tabular}{|c|c|c|c|c|c|}
\hline \multirow[b]{2}{*}{ Sampling period } & \multicolumn{4}{|c|}{ Neighborhood } & \multirow[b]{2}{*}{$*$ F value } \\
\hline & I & II & III & IV & \\
\hline $07 / 1990 \sim 06 / 1991$ & $\begin{array}{l}12.28 \pm 7.9 \\
(n=100)\end{array}$ & $\begin{array}{l}11.65 \pm 3.7 \\
(n=108)\end{array}$ & $\begin{array}{l}10.55 \pm 5.7 \\
(n=158)\end{array}$ & $\begin{array}{l}10.81 \pm 8.5 \\
(n=128)\end{array}$ & $\begin{array}{l}4.46 \\
(P=0.0042)\end{array}$ \\
\hline $07 / 1992 \sim 06 / 1993$ & $\begin{array}{l}8.71 \pm 4.3 \\
(\mathrm{n}=93)\end{array}$ & $\begin{array}{l}8.35 \pm 3.0 \\
(n=63)\end{array}$ & $\begin{array}{l}8.46 \pm 3.0 \\
(\mathrm{n}=37)\end{array}$ & $\begin{array}{l}9.13 \pm 2.5 \\
(\mathrm{n}=123)\end{array}$ & $\begin{array}{l}1.01 \\
(P>0.05)\end{array}$ \\
\hline $\begin{array}{l}* * \text { t value } \\
\mathrm{p} \text { value }\end{array}$ & $\begin{aligned} & 3.86 \\
< & 0.001\end{aligned}$ & $\begin{array}{c}6.31 \\
<0.001\end{array}$ & $\begin{array}{r}2.16 \\
<0.05\end{array}$ & $\begin{array}{r}2.11 \\
<0.05\end{array}$ & \\
\hline
\end{tabular}

* Test for four neighborhoods

** Test for two sampling periods of each neighborhood

Table 3. Paired t-test for high average blood lead levels $(>15 \mu \mathrm{g} / \mathrm{dl})$ collected from four neighborhoods during two sampling periods. Data are presented as mean \pm 1 s.d.

\begin{tabular}{|c|c|c|c|c|c|}
\hline \multirow[b]{2}{*}{ Sampling period } & \multicolumn{4}{|c|}{ Neighborhood } & \multirow[b]{2}{*}{ Total average } \\
\hline & I & II & III & IV & \\
\hline $07 / 1990 \sim 06 / 1991$ & $20.25 \pm 4.3$ & $18.38 \pm 3.2$ & $18.44 \pm 3.1$ & $19.25 \pm 4.0$ & $18.84 \pm 3.3$ \\
\hline $07 / 1992 \sim 06 / 1993$ & $15.50 \pm 6.0$ & $10.88 \pm 1.8$ & $12.78 \pm 3.0$ & $11.75 \pm 2.2$ & $12.44 \pm 3.4$ \\
\hline Difference of average & 4.75 & 7.50 & 5.66 & 7.50 & $6.40 \pm 3.6$ \\
\hline
\end{tabular}

$\mathrm{t}=8.79, \mathrm{df}=24, \mathrm{p}<0.001$

t-test analysis, the blood lead levels collected from different residential neighborhoods differed significantly $(\mathrm{p}<0.05)$ from those from lead-unpolluted areas. In other words, in the lead-unpolluted area, blood lead had lower concentrations probably because of their remote locations (i.e., away from pollution sources).

Life style may influence lead absorption (Berode et al. 1991). Environmental factors such as living in an area with high traffic density, occupational hobbies, and the age of dwelling may also influence the exposure to lead (Huel et al. 1986; Quinn and Delves 1987; Ducoffre et al. 1990). Because sampling was done on the same group of residents, Table 3 shows the paired t-test for high average blood lead levels $(>15 \mu \mathrm{g} / \mathrm{dl}$ ) collected from four neighborhoods during two sampling periods. The results reveal that the two-year average difference of blood lead levels is in the range of 4.75 to $7.50 \mu \mathrm{g} / \mathrm{dl}$. Generally, a review of data shows that the 4 locations had the higher average concentration of lead in blood (range from $18.38 \pm 3.2$ to $20.25 \pm 4.3$ $\mu \mathrm{g} / \mathrm{dl}$ ) during July 1990 to June 1991 , but decreasing levels (range from $10.88 \pm 1.8$ to $15.50 \pm 6.3 \mu \mathrm{g} / \mathrm{dl}$ ) have been observed significantly $(p<0.001)$ because a program has been implemented by EPA to reduce the pollution in this area.

\section{Lead in Various Environmental Samples}

The results of analysis for lead concentrations in water, sediments, soils, and air collected from different locations during two periods are listed in Tables 4-8. Table 4 shows the geometric mean concentrations of lead in various water bodies. The Tawulum River was particularly affected by lead. The total lead concentrations $(\mathrm{GM}=128$ and $5.84 \mu \mathrm{g} / \mathrm{L})$ in downstream river water were higher than those $(\mathrm{GM}=28.7$ and $2.21 \mu \mathrm{g} / \mathrm{L})$ in upstream river water during the periods from July 1990-June 1991 and July 1992-June 1993, respectively. The high lead concentrations in downstream river water apparently reflect a local anthropogenic input of pollutants, especially lead (Han et al. 1991, 1992a). 
Table 4. Geometric mean lead concentrations $(\mu \mathrm{g} / \mathrm{L})$ in river, tap, and well water during two sampling periods

\begin{tabular}{|c|c|c|c|c|}
\hline \multirow[b]{3}{*}{ Water samples } & \multicolumn{4}{|l|}{ Sampling periods } \\
\hline & \multicolumn{2}{|c|}{$07 / 1990 \sim 06 / 1991$} & \multicolumn{2}{|c|}{$07 / 1992 \sim 06 / 1993$} \\
\hline & No. of samples & $\mathrm{Pb}$ concn. & No. of samples & $\mathrm{Pb}$ concn. \\
\hline $\begin{array}{l}\text { Upstream* } \\
\text { river water }\end{array}$ & 10 & $\begin{array}{l}28.7 \\
(10.5 \sim 76.7)\end{array}$ & 20 & $\begin{array}{l}2.21 \\
(0.31 \sim 27.3)\end{array}$ \\
\hline $\begin{array}{l}\text { Downstream* } \\
\text { river water }\end{array}$ & 12 & $\begin{array}{l}128 \\
(24.9 \sim 1450)\end{array}$ & 24 & $\begin{array}{l}5.84 \\
(0.78 \sim 626)\end{array}$ \\
\hline Tap water & 39 & $\begin{array}{l}2.06 \\
(0.83 \sim 12.2)\end{array}$ & 37 & $\begin{array}{l}1.82 \\
(0.49 \sim 8.43)\end{array}$ \\
\hline Well water & 6 & $\begin{array}{l}8.71 \\
(4.80 \sim 38.8)\end{array}$ & 5 & $\begin{array}{l}3.75 \\
(3.02 \sim 6.62)\end{array}$ \\
\hline
\end{tabular}

*Using the Shing-Yie plant as the division point: sampling sites located north of the plant are classified as upstream, and those located south of the plant are classified as downstream

( ) = Two extreme values

Table 5. Geometric mean lead concentrations $(\mu \mathrm{g} / \mathrm{g})$ in Tawulum River sediments during two sampling periods

\begin{tabular}{|c|c|c|c|c|}
\hline \multirow[b]{3}{*}{ River section } & \multicolumn{4}{|l|}{ Sampling periods } \\
\hline & \multicolumn{2}{|c|}{$07 / 1990 \sim 06 / 1991$} & \multicolumn{2}{|c|}{$07 / 1992 \sim 06 / 1993$} \\
\hline & No. of samples & $\mathrm{Pb}$ concn. & No. of samples & $\mathrm{Pb}$ conen. \\
\hline Upstream* & 6 & $\begin{array}{l}123 \\
(80.2 \sim 272)\end{array}$ & 25 & $\begin{array}{l}158 \\
\quad(3.53 \sim 4397)\end{array}$ \\
\hline Downstream* & 12 & $\begin{array}{l}372 \\
(203 \sim 920)\end{array}$ & 30 & $\begin{array}{l}418 \\
(17.9 \sim 2023)\end{array}$ \\
\hline
\end{tabular}

*Using the Shing-Yie plant as the division point: sampling sites located north of the plant are classified as upstream, and those located south of the plant are classified as downstream

$($ ) $=$ Two extreme values

Table 6. The chemical forms of lead $(\mu \mathrm{g} / \mathrm{g})$ in river sediments collected from three stations (during $7 / 1990 \sim 6 / 1991$ )

\begin{tabular}{|c|c|c|c|c|c|c|c|}
\hline \multirow{2}{*}{$\begin{array}{l}\text { Sampling } \\
\text { station }\end{array}$} & \multicolumn{6}{|l|}{$\mathrm{Pb}$ phases* } & \multirow[b]{2}{*}{ Total** } \\
\hline & I & II & III & IV & V & $\mathrm{VI}$ & \\
\hline $\mathbf{R}_{1}$ & $\begin{array}{l}4.12 \\
(3.11)^{* * * *}\end{array}$ & $\begin{array}{c}23.2 \\
(17.5)\end{array}$ & $\begin{array}{c}31.3 \\
(23.7)\end{array}$ & $\begin{array}{c}23.7 \\
(17.5)\end{array}$ & $\begin{array}{c}8.07 \\
(6.11)\end{array}$ & $\begin{array}{c}42.3 \\
(32.0)\end{array}$ & 132 \\
\hline $\mathrm{R}_{2}$ & $\begin{array}{l}146 \\
(12.4)\end{array}$ & $\begin{array}{l}223 \\
(19.0)\end{array}$ & $\begin{array}{l}615 \\
(52.3)\end{array}$ & $\begin{array}{l}102 \\
(8.67)\end{array}$ & $\begin{array}{l}17.4 \\
(1.48)\end{array}$ & $\begin{array}{l}72.5 \\
(6.16)\end{array}$ & 1176 \\
\hline $\mathrm{R}_{3}$ & $\begin{array}{c}70.5 \\
(21.0)\end{array}$ & $\begin{array}{c}78.2 \\
(23.3)\end{array}$ & $\begin{array}{c}54.3 \\
(16.2)\end{array}$ & $\begin{array}{c}73.8 \\
(22.0)\end{array}$ & $\begin{array}{l}22.5 \\
(6.71)\end{array}$ & $\begin{array}{c}36.3 \\
(10.8)\end{array}$ & 335 \\
\hline
\end{tabular}

*I: Exchangeable phase; II: Carbonates phase; III: Easily reducible Fe-Mn oxides phase; IV: Moderately reducible Fe-Mn oxides phase; V: Organic phase; VI: Residual phase

** Total: I+II+III+IV +V + VI

$* * *(\quad)$ : percent of total

The geometric mean concentrations of lead in drinking water (including well water) ranged from 1.82 to $8.71 \mu \mathrm{g} / \mathrm{L}$. All data were within the limits of standard drinking water set by the EPA of ROC.

Concentrations of lead in sediments are so much higher than those in the overlying water that even a small fraction may represent an important source for potential risk (Bryan et al. 1985; Gunn et al. 1991). Table 5 shows that the geometric mean lead concentrations in the river sediment varied with sampling period and location. The concentrations of lead $(\mathrm{GM}=372$ and $418 \mu \mathrm{g} / \mathrm{g}$ ) in the downstream river sediments were significantly higher $(\mathrm{p}<0.05$ and 0.06 ) than those ( $\mathrm{GM}=123$ and $158 \mu \mathrm{g} / \mathrm{g}$ ) in the upstream river sediments during the periods from July 1990-June 1991 and July 1992June 1993, respectively; this might be due to a contribution of lead pollutants discharged from the land pollution sources, especially the plant.

Furthermore, lead species in sediments such as exchangeable (phase I), carbonates (phase II), easily reducible $\mathrm{Fe}$ and $\mathrm{Mn}$ oxides (phase III), resistant crystalline Mn oxides (phase IV), residual organic matter and sulphides (phase $V$ ), and lattice held material (phase VI) were analyzed by a sequential leaching 
Table 7. The chemical forms of lead $(\mu \mathrm{g} / \mathrm{g})$ in dust at the soil surface collected from five stations (during 7/1990 6/1991)

\begin{tabular}{|c|c|c|c|c|c|c|c|c|}
\hline \multirow{2}{*}{$\begin{array}{l}\text { Sampling } \\
\text { station }\end{array}$} & \multirow{2}{*}{$\begin{array}{l}\text { Distance from } \\
\text { plant }(m)\end{array}$} & \multicolumn{6}{|c|}{$\mathrm{Pb}$ phases* } & \multirow[b]{2}{*}{ Total** } \\
\hline & & I & II & III & IV & V & VI & \\
\hline$S_{1}$ & 10 & $\begin{array}{l}960 \\
(26.7)\end{array}$ & $\begin{array}{l}1760 \\
(49.0)\end{array}$ & $\begin{array}{l}366 \\
(10.2)\end{array}$ & $\begin{array}{l}406 \\
(11.3)\end{array}$ & $\begin{array}{l}38.1 \\
(1.06)\end{array}$ & $\begin{array}{l}60.2 \\
(1.68)\end{array}$ & 3590 \\
\hline$S_{2}$ & 20 & $\begin{array}{l}290 \\
(21.1)\end{array}$ & $\begin{array}{l}332 \\
(24.2)\end{array}$ & $\begin{array}{l}510 \\
(37.1)\end{array}$ & $\begin{array}{l}118 \\
(8.58)\end{array}$ & $\begin{array}{l}24.7 \\
(1.80)\end{array}$ & $\begin{array}{l}100 \\
(7.27)\end{array}$ & 1374 \\
\hline $\mathrm{S}_{3}$ & 1000 & $\begin{array}{c}31.5 \\
(20.9)\end{array}$ & $\begin{array}{c}21.0 \\
(13.9)\end{array}$ & $\begin{array}{c}20.2 \\
(13.4)\end{array}$ & $\begin{array}{c}42.5 \\
(28.1)\end{array}$ & $\begin{array}{c}19.7 \\
(13.1)\end{array}$ & $\begin{array}{c}16.3 \\
(10.8)\end{array}$ & 151 \\
\hline
\end{tabular}

*I: Exchangeable phase; II: Carbonates phase; III: Easily reducible Fe-Mn oxides phase; IV: Moderately reducible Fe-Mn oxides phase; V: Organic phase; VI: Residual phase

** Total: $\mathrm{I}+\mathrm{II}+\mathrm{III}+\mathrm{IV}+\mathrm{V}+\mathrm{VI}$

$* * *(\quad): \mathrm{I} \sim \mathrm{VI} /$ total $\times 100 \%$

Table 8. Geometric mean lead concentrations $\left(\mu \mathrm{g} / \mathrm{m}^{3}\right)$ in air samples from four stations during two sampling periods

\begin{tabular}{|c|c|c|c|c|c|}
\hline \multirow{3}{*}{$\begin{array}{l}\text { Sampling } \\
\text { station }\end{array}$} & \multirow{3}{*}{$\begin{array}{l}\text { Distance from } \\
\text { plant (m) }\end{array}$} & \multicolumn{4}{|c|}{ Sampling periods } \\
\hline & & \multicolumn{2}{|c|}{$07 / 1990 \sim 06 / 1991$} & \multicolumn{2}{|c|}{$07 / 1992 \sim 06 / 1993$} \\
\hline & & No. of samples & $\mathrm{Pb}$ concn & No. of samples & $\mathrm{Pb}$ conen \\
\hline$A_{1}$ & 5 & 21 & $\begin{array}{l}4.57 \\
(0.102 \sim 37.6)\end{array}$ & 35 & $\begin{array}{l}0.244 \\
(0.001 \sim 2.47)\end{array}$ \\
\hline $\mathrm{A}_{2}$ & 300 & 18 & $\begin{array}{l}1.26 \\
(0.040 \sim 18.2)\end{array}$ & 20 & $\begin{array}{l}0.027 \\
(0.001 \sim 0.993)\end{array}$ \\
\hline $\mathrm{A}_{3}$ & 900 & 8 & $\begin{array}{l}0.66 \\
(0.14 \sim 2.20)\end{array}$ & 29 & $\begin{array}{l}0.003 \\
(0.001 \sim 0.128)\end{array}$ \\
\hline $\mathrm{A}_{4}$ & 1100 & 5 & $\begin{array}{l}0.08 \\
(0.02 \sim 0.35)\end{array}$ & 33 & $\begin{array}{l}0.002 \\
(0.001 \sim 0.096)\end{array}$ \\
\hline
\end{tabular}

$(\quad)$ Two extreme vaiues

technique (Table 6). The results show that the highest lead concentration of $146 \mu \mathrm{g} / \mathrm{g}$ in the exchangeable phase was obtained from the sediment of station $\mathrm{R}_{2}$. This result reveals that the exchangeable lead in sediment collected from station $R_{2}$ was 2.07-35.4 times higher than that from other stations. In addition, the sum of phases I, II, and III accounts for $83.7 \%$ of total lead at station $R_{2}$. This might suggest that station $R_{2}$ seems to be influenced by the local anthropogenic input of chemicals, especially lead. In other words, lead speciation results reveal that the lead preferentially accumulated in the exchangeable, carbonate, and easily reducible Fe-Mn oxides fractions. The lead pollution source in sediments was the storage battery recycling plant (Han et al. 1991, 1992b).

Because blood lead levels can reflect lead concentrations in local soils and dusts (Thornton et al. 1990), an assessment of the potential health threat from lead in soils and dusts is imperative. The dust-hand-mouth route may be a predominant form of lead exposure during early childhood; therefore, the lead concentrations in dust and soils were examined. Figure 3 shows the lead concentrations in soil surface dust and the surface soils sampled at varying distances from the plant during July 1990-June 1991 and July 1992-June 1993. Maximum geometric mean lead concentrations $(2,402 \mu \mathrm{g} / \mathrm{g})$ in soil surface dust at station $S_{1}$ were much higher than those from the other stations by about 18 times in July 1990-June 1991. The highest concentration of lead obtained at the station $S_{1}$ nearest to the ShingYie plant might be due to lead pollutants discharged from smelting sources. However, after one year amelioration, the lead concentration in soil surface dust at station $S_{1}$ dropped to $1,155 \mu \mathrm{g} / \mathrm{g}$. However, when the soil depth was increased to $15-30 \mathrm{~cm}$, the lead concentrations in the soil decreased to $<100 \mu \mathrm{g} / \mathrm{g}$.

The data obtained showed that the lead concentrations in dust (zero soil depth) and the surface soils $(0-15$ and $15-30 \mathrm{~cm})$ during July 1992 to June 1993 were, respectively, 2.08-4.24, 3.01-8.66, and 1.37-5.04 times less than those during July 1991 to June 1992 because a program has been implemented by the plant and EPA to reduce the pollution in this area (Han et al. 1993). On the other hand, an inverse relationship was observed between soil lead levels and the sample distance from the Shing-Yie plant (Figure 3). On the whole, the environmental data showed that the geometric mean value of lead in dust at the soil surface near Shing-Yie was $>1000 \mu \mathrm{g} / \mathrm{g}$ and decreased to $<100 \mu \mathrm{g} / \mathrm{g}$ in $15-30 \mathrm{~cm}$ depth soil about $2 \mathrm{~km}$ away from the plant. In general, the concentrations of lead in soils were strongly and negatively correlated with the distance from the Shing-Yie plant.

Table 7 shows the result of lead speciation in dust at the soil surface extracted by sequential procedures using several reagents. The results reveal that lead is preferentially accumulated in the exchangeable and carbonate fractions. For example, the total lead concentration of $3,590 \mu \mathrm{g} / \mathrm{g}$ in dust of station $S_{1}$ was higher than those in dust of the other stations. In addition, the sum of exchangeable and carbonate lead gave a higher percentage $(75.7 \%)$ of lead in the station $S_{1}$ dust. This suggests that the lead pollution is dominated synchronously by the Shing- 


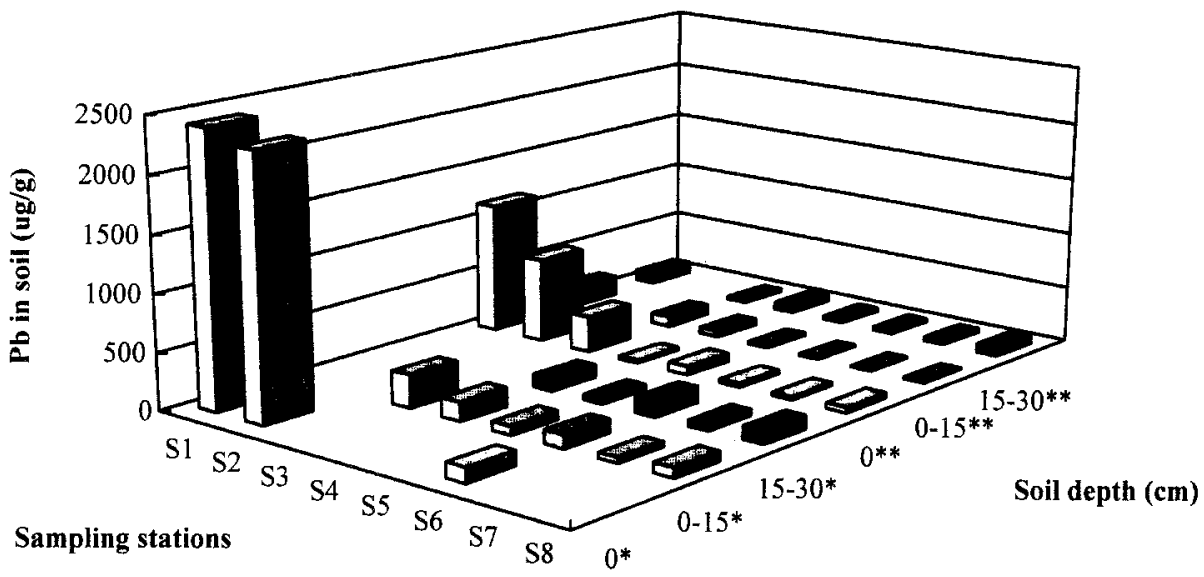

Fig. 3. Geometric mean lead concentrations in the surface dust (zero soil depth) and the surface soil (0-15 and $15-30 \mathrm{~cm}$ ) sampled at varying distances from the Shing-Yie plant during July 1990-June $1991\left(^{*}\right)$ and July 1992-June 1993 (**) $^{* *}$
Yie plant. In the present study, the lower traffic volume caused no significant influence on lead concentrations for these areas. In general, the exposure risk due to lead-contaminated dusts and soils is in large areas where dilapidated housing is present and traffic volumes are high (Mielke 1991). Residents of smaller cities generally face a lower lead burden because large tracts of run-down housing are lacking and traffic volumes are low (Mielke 1992).

In 1992, the range of air lead concentration in high polluted cities of Taiwan were $0.3-0.6 \mu \mathrm{g} / \mathrm{m}^{3}$ (Han et al. 1993). However, during July 1990 to June 1991, the geometric mean concentrations of lead of $4.57 \mu \mathrm{g} / \mathrm{m}^{3}$ (from 0.102 to $37.6 \mu \mathrm{g} / \mathrm{m}^{3}$ ) in the air near the Shing-Yie plant were higher than those at the background locations, the mean value of which was 0.08 $\mu \mathrm{g} / \mathrm{m}^{3}$. The results indicated that the highest lead in air from station $A_{1}$ is 57 times more than that in air from station $A_{4}$ (Table 8). In other words, on average, sampling stations located closer to the Shing-Yie plant had higher lead in their air than sampling stations located further away (Table 8). In addition, the concentrations of lead in air collected from the same station (A1) were below $0.244 \mu \mathrm{g} / \mathrm{m}^{3}$ after July 1992. This demonstrates that the Shing-Yie plant lowered its pollution.

Acknowledgments. We would like to thank Professor T.J. Hsu of the School of Public Health, Taipei Medical College, for making chemical analyses possible in this study. We are grateful to two reviewers for constructive comments and suggestions. This study was supported by grants from the Environmental Protection Bureau of Keelung City and the Environmental Protection Administration of the Republic of China.

\section{References}

Berode M, Wietlisbach V, Rickenbach M, Guillemin MP (1991) Lifestyle and environmental factors as determinants of blood lead levels in a Swiss population. Environ Res 55:1-17

Bryan GW, Langston WJ, Hummerstone LG, Burt GR (1985) A guide of the assessment of heavy-metal contamination in estuaries using biological indicators. Mar Biol Ass UK, Plymouth, Devon, UK, Occasional Publication No. 4

Chi YM, Chen SL, Yang MH, Hwang RC, Chu ML (1993) Heavy metals in traditional Chinese medicine: Ba-pao-neu-hwang-san. Acta Paedi Sinica 34:181-190

Ducoffre G, Claeys F, Bruaux P (1990) Lowering time trend of blood lead levels in Belgium since 1978. Environ Res 51:25-34
Francek MA, Makimaa B, Pan V, Hanko JH (1994) Small town lead levels: A case study from the homes of pre-schoolers in Mt. Pleasant, Michigan. Environ Pollut 84:159-166

Greene T, Ernhart CB, Boyd TA (1992) Contributions of risk factors to elevated blood dentine lead levels in preschool children. Sci Total Environ 115:239-260

Gunn AM, Winnard DA, Hunt DTE (1991) Trace metal speciation in sediments and soils. In: Kramer JR, Allen HE (eds) Metal speciation theory, analysis, and application. Lewis Publishers, pp 26I-294

Han BC, Chiou HI, Yeh CY, Hsu TJ (1991) The epidemiological study on environmental lead contamination near a battery recycling plant (I). Technical Report (EPA-80-F102-09-42), 102 p, Environmental Potection Administration, Taipei, Taiwan, ROC

Han BC, Chen RY, Yeh CY, Hsu TJ (1993) The epidemiological study on environmental lead contamination near a battery recycling plant (II). Technical Report (EPA-82-F102-09-42), 102 p, Environmental Protection Administration, Taipei, Taiwan, ROC

Han BC, Chen RY, Chiou HI, Yeh CY, Hsu TJ (1994a) Distribution of lead pollution in soil and air around a storage battery recycling plant. J Natl Public Health Assoc (ROC) 13:126-137

Han BC, Jeng WL, Jeng MS, Hung TC (1994b) Copper intake and health threat by consuming seafood from copper contaminated coastal environments in Taiwan. Environ Toxicol Chem 13:775-780

Han BC, Chiou HI, Chen RY, Yeh CY, Hung TC (1992a) Speciation of lead pollution in water and sediments around a battery recycling plant. J Chin Environ Prot Soc 15:64-74

Han BC, Jeng WL, Hung TC (1992b) Assessment of copper complexing capacity in sediments. $J$ Chin Inst Environ Eng 2:255-262

Huel G, Boudene C, Jouan M, Lazar P (1986) Assessment of exposure to lead of the general population in the French community through biological monitoring. Int Arch Occup Environ Health 58:131-139

Jang CS (1989) Study of lead recycling factory's occupational and environmental disease (in Chinese). Master's Thesis, National Taiwan University, Department of Public Health, Taipei, Taiwan, ROC

Jeng WL, Han BC (1994) Sedimentary coprostanol in Kaohsiung Harbour and the Tan-Shui estuary, Taiwan. Mar Pollut Bull 28:494-499

Mielke HW (1991) Lead in residential soils: Background and preliminary results of New Orleans. Water Air Soil Pollut 57-58:111-119

- (1992) Lead dust contaminated U.S.A. communities: Comparison of Louisiana and Minnesota. Appl Geochem 6:1-5

Needleman HL, Schell A, Bellinger D, Leviton A, Allred EN (1990) The long-term effects of exposure to low doses of lead in childhood: An 11-year follow-up report. N Engl J Med 332:83-88

Quinn MJ, Delves HT (1987) UK blood lead monitoring programme 
1984-1987: Protocol and result for 1984, Human Toxicol 6:459-474

Rabinowitz M, Wang JD, Soong WT (1991) Dentine lead and child intelligence in Taiwan. Arch Environ Health 46:351-360

(1992) Children's classroom behavior and lead in Taiwan. Bull Environ Contam Toxicol 48:282-288
Thornton I, Davies DJA, Watt JM, Quinn MJ (1990) Lead exposure in young children from dust and soil in the United Kingdom. Environ Health Persp 89:55-60

Wang JD, Jang CS, Hwang YH, Chen ZS (1992) Lead contamination around a kindergarten near a battery recycling plant. Bull Environ Contam Toxicol 49:23-30 